\title{
Review: Challenges and opportunities of implementing mass production scale (MPS) at date farms in Malaysia
}

Asmaddy Haris*, Aimi Fadzirul Kamarubahrin, Siti Nurazira Mohd Daud, Zurina Kefeli @ Zulkefli, Nursilah Ahmad, Nurul Aini Muhamed and Syadiyah Abdul Shukor

Faculty of Economics and Muamalat, Universiti Sains Islam Malaysia

Bandar Baru Nilai, 71800 Nilai, Negeri Sembilan, Malaysia

*Corresponding author: hasmaddy@usim.edu.my

Received: $15^{\text {th }}$ November 2018; Revised: 27 th January 2020; Accepted: $28^{\text {th }}$ January 2020

\section{Keywords:}

Challenges,

dates farm, mass

productivity scale

(MPS), opportunities.

\begin{abstract}
The study aimed to review the challenges and opportunities of mass productivity scale (MPS) for the dates (Phoenix dactylifera L.) farm in Malaysia. The review on site and document was done to drill the issues faced by dates palm farmers. The common issues affecting dates farm in Malaysia were pest attack, import permit, lack of expertise, and climate and soil requirements. In a united response, the government should form the National Dates Palm Centre (NDPC) which will explore opportunities to address issues faced by the dates palm sector in Malaysia.
\end{abstract}

\section{INTRODUCTION}

Growing population affects the equivalent claim for food, particularly food beneficial to human health (Kamarubahrin et al., 2018b), like date (P. dactylifera L.), a fruit recommended by the Prophet Muhammad (pbuh) (Kamarubahrin et al., 2019, Haris et al., 2019). Hence, it leads to the increasing of date farm to fulfill the need for dates (Kamarubahrin et al., 2018a). In the last two decades, growing market demand for date fruit has resulted in the establishment of commercial date farms in several Southeast Asian countries, such as Thailand and Indonesia, due to scientific hybrid process of date trees. (Al-Yahyai and Manichavasagan, 2012, Apriyanti et al., 2015, Djamil, 2016). Malaysia also purposefully produces this fruit in small-scale farming for domestic consumption due to its newly found scientific evidence that this crop can be planted and grown in this country (Kamarubahrin et al., 2018a).

Not many have known that Malaysia has stareted planting and producing date fruits. In fact, this fruit is commonly consumed by Malaysian especially by Muslims because of the religious practices and availability (Umar et al., 2016, Rani et al., 2016, Haris et al., 2019, Kamarubahrin, 2019), but low local producing made Malaysia suffer from imported dates. Despite large volume of date import every year, Malaysia also produces local dates in small scale farm concept. Unfortunately, these smallholder farmers lack of knowledge and information about standard farm management of dates, resulting in poor farm production practice and methods (Young, 2010, Al-Kharusi et al., 2019). Hence, the presence of small scale farming with low production of dates can be seen as such a potential matter to improve this sector.

This review identified perspectives of numerous stakeholders on the economics and organizational challenges which affect date farms in Malaysia. In advance, it shows how date farms challenges can be turned into a promising potential influencing the productivity towards the goal of MPS implementation. Thus, this study presented the challenges and opportunities of MPS for the date (P. dactylifera $\mathrm{L}$.) farms in Malaysia. Herewith, this paper's structure is first, the introduction. The second one is further information regarding dates. The explanation about 


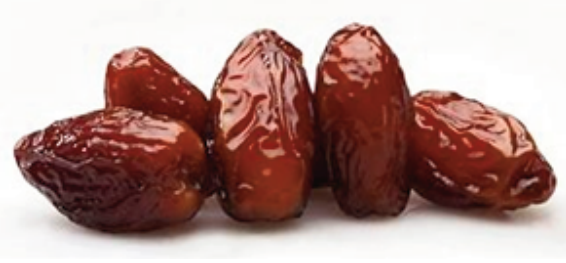

Figure 1. The date palm (P. dactylifera L.)

nutritional value is taking the third section. The fourth is explaining religious perspectives on dates. The fifth section will describe current practices of date farms in Malaysia, followed by the challenges and opportunities of the study. The final one is the conclusion of this study.

\section{DATES}

Date (P. dactylifera L.), as shown in Figure 1 is an angiosperm monocotyledonous plant that is the part of Arecaceae (syn. Palmaceae) family from more than 200 generations (Dowson, 1982). The genus Phoenix contains 12 out of 1,500 species which are the parts of date palm family (Kamarubahrin et al., 2018a). In Arabic, date palm tree is called "nakhl" while the fruit is called "tamr". Among the main top fruits in Middle East, P. dactylifera $\mathrm{L}$. is also listed (Haris and Kamarubahrin, 2016; Haris et al., 2017). In Middle East and North Africa, date palm has been cultivated for millennia; however, the exact origin of date palm has not been verified yet. Zaid and de Wet (2002) cited the reports of its use in Mesopotamian times since 4000 BC (Popenoe, 1973) and by the Egyptians perhaps during 3000-2000 BC (Al-Yahyai and Manichavasagan, 2012). According to Zaid and de Wet (2002), the African dates ( $P$. reclinata) or the Indian dates ( $P$. sylvestris) or both may have been the progenitor of date palm. The majority of date palm-growing areas was set in developing or underdeveloped countries wherever dates were thought of as the first food crop, so it took part in a significant role within the nutrition standing of those communities (Al-Yahyai and Manichavasagan, 2012).

For many households in Malaysia, especially for Muslims, P.dactylifera L. is a common fruit. Its nutritional constituents are considered valuable for vast medicinal properties (Mohamed et al., 2018). Dates have been known as the extremely alimentary food with several useful advantages to human health. (Haris and Kamarubahrin, 2016). Dates are reviewed for their phytochemical compositions, mineral, and proximate, and number of authors have considered the worth of dates which appear as "healthy" fruit (Al-Farsi et al., 2008; Vayalil, 2012). Dates are rich with many sources such as fibre, vitamins and minerals (Serhane et al., 2017). The dates contain sulphur, potassium, phosphorus, manganese, calcium, oil, iron, magnesium and copper. Eating dates can even offer relief from constipation, viscus disorders, heart issues, anaemia, diarrhoea, abdominal cancer and lots of health issues. They are also known to have inhibitor and anti-mutagenic properties, and to treat heart disease (Ismail et al., 2006).

Dates have a high extent substance of sugars (all out sugars, $44 \%-88 \%)$, minerals, fifteen protein and salts $(2.3 \%-5.6 \%)$, fat $(0.2 \%-0.5 \%)$, a high extent of dietary fiber (6.4-11.5\%) and nutrients. In the meantime, $0.2 \%-0.5 \%$ of oil are accessible from the date tissue, while the seed comprises $7.7 \%-9.7 \%$ oil. The heaviness of the seed is $5.6 \%-14.2 \%$ of the dates (Al-Farsi et al., 2008). The unsaturated fats exist in each fragile living creature and seed is the assortment of soaked and unsaturated acids. The seeds consist of fourteen sorts of unsaturated fats, eight of which are found in awfully low fixation inside the substance (Al-Shahib and Marshall, 2003). Linoleic, palmitoleic, linolenic acids and oleic exemplify the unsaturated fats. The monounsaturated fat substance of the seed changes from $41.1 \%$ to $58.8 \%$ proposing that the date seeds could likely be utilized as a stockpile of monounsaturated fat. There are least of 15 minerals in dates. The extent of each mineral in dried dates changes from $0.1 \%$ to $916 \mathrm{mg} .100 \mathrm{~g} \mathrm{~g}^{-1}$, looking from the sort of mineral (Apriyanti et al., 2015). 


\section{RELIGIOUS PERSPECTIVES}

Besides health perspectives, three major religions in the world has shown the significance of dates based on verses in the holy book. In Islam, P. dactylifera $\mathrm{L}$. is cited 21 times in Quran and 300 times in the Hadith of the Prophet Mohammed (pbuh), creating it out and away the foremost oftentimes cited plant (Al-Yahyai and Manichavasagan, 2012). Similarly, P. dactylifera $\mathrm{L}$. is praised in Christian and Judaism faiths and has been joined in various religious ceremonies like Passover and Christian holy day (Musselman, 2007). Date is a symbol associated with Islam and Muslims (Kamarubahrin, 2019, Kamarubahrin et al., 2019) as it is followed in Prophet Muhammad's (pbuh) sunnah (Practice or consume what Prophet Muhammad (pbuh) eat or drink daily) (Kamarubahrin et al., 2018a). The Prophet Muhammad (pbuh) said: "Ajwah dates are from Paradise" (Hadith No.2068, AlTirmidhi).

There is also another hadith narrated by Anas ibn Malik stating that: "The Prophet Muhammad (pbuh) used to break his fast before praying with some fresh dates; but if there were no fresh dates, he had a few dry dates, and if there were no dry dates, he took some mouthfuls of water "(Hadith No.2349, Sunan Abu Dawood). Meanwhile, P. dactylifera L. is mentioned over the other fruit-bearing plants in Quran. One of the verses states: "In the earth there are diverse regions side by side and gardens of grapes and cultivated fields, and date-palms sharing one root and others with individual roots, all watered with the same water. And, we make some things better to eat than others. There are signs in that for people who use their intellect" (Quran: Ar-Ra'd 13:4). During Ramadhan festive, date is a very common food for a Muslim diet. The demand for date fruits especially among the consumers due to their regular consumption would be an advantage for Malaysia's economic growth.

\section{CURRENT PRACTICES OF FARMING}

Date palm cultivation is encouraged due to health and economic benefits. Moreover, consumption of dates is supported by evidence from Quran verses and practices by the Prophet Muhammad (pbuh). Thus, date farming practices was introduced into Malaysia in late 2010. It can be found at East-Coast region such as Kelantan and Terengganu. Date farms are also available in Northern of Malaysia, which is at Johore (Zainal, 2016). In fact, most of the privateowned farms found is operated as fundamental sector and at the primary stages of cultivation. Malaysia which have a mass production of dates farm is still unproven by which observation and search engine data. Several of dates farm found are still at the early stage, which is in the process of cultivating the date palm seed. So it is obvious that production of date palms is extremely rare in Malaysia context.

Regardless the extremely rare production, the annual export of date palms in Malaysia from 2010 to 2013 was 12,258 tons (FAO, 2015; FAMA, 2014). Normally, Malaysia is not the date palm producer but they imported and generated additional value of date fruits for its commercial benefits by considering the use of date industry by-products. Meanwhile, the annual date palm imported to Malaysia was estimated at 19,000 to 20,000 tons, and almost $75 \%$ of which was Iranian dates (FAMA, 2014). Table 1 shows the total export and import of Malaysia dates. From the 2010 to the 2013, Malaysia production (export) decreased dramatically. Within the decrease, it continued to grow in the 2012 and decreased again in 2013.

On account of large number of imported dates in Malaysia, it clearly shows the high demand for date palm products. That led to Malaysia government's action to gear up the agriculture sectors (ETP, 2010). The scarcity of local date production has resulted in

Table 1. Malaysia total export and import of dates

\begin{tabular}{lccccc}
\hline $\begin{array}{c}\text { Total Export and Import } \\
\text { (tons) }\end{array}$ & 2010 & 2011 & 2012 & 2013 & Total \\
\hline Export & 4,268 & 3,906 & 2,430 & 1,654 & 12,258 \\
Import & 17,980 & 16,236 & 20,394 & 19,421 & 74,031 \\
\hline
\end{tabular}

Source: FAO (2015); FAMA (2014) 
this country suffering from import. Malaysia imported both dried and fresh of dates from Middle East countries and Pakistan (Abul-Soad, 2010). Date palm farming was introduced to Malaysia in late 2010. Private date palm farming scheme was established in Kelantan and Terengganu and Johore (Zainal, 2016). However, this sector is still at the preliminary stages. That's why there is a paucity of research into the different aspects of date palm farming in term of the challenges and opportunities.

\section{CHALLENGES}

In spite of the presence of demand on dates, current date palm farms in Malaysia are still far from commercialization for industry and even for commodity scale. Such farms are supposed to have a quick development under farming industry in the country and a potentially profitable venture, although it is still in its infancy. However, there are issues and challenges farmers need to face in the development and improvement of the date palm farming.

Majorly common issues and challenges found in countries producing dates are related to diseases and pests, import permit, lack of expertise, and climate and soil requirements (Shri and Dennis, 2015; Kamarubahrin et al., 2018a). Those are believed to be faced as well in Malaysia context. The followings are the most specific and detailed ones faced in Malaysia.

\section{Insect Pest Attack}

The insect pest types that are common to dates palm is the red palm weevil (Rhynchophorus ferrugineus Olivier) and the dubas bug (Ommatissus lybicus Bergevin) (Al-Yahyai and Manichavasagan, 2012). These two damaging irritations of date palm strike the stem and if untreated can kill the tree. Until present time, exceptionally powerful control measures have yet to be found. Sadly, that creepy crawly bug type, the red palm weevil, is the starting point from tropical South Asian (Al-Kharusi et al., 2019). Moreover, the illnesses are also caused essentially by parasites and phytoplasma, for example, deadly yellowing and Bayoud Fusarium shrink, which are the danger to the date palm in Malaysia. Consequently, the date palms in Malaysia are exceptionally uncovered with this irritation assault as observed by different nations in different districts on the planet.

\section{Import Permit}

Recorded by the department of agriculture, there is no import permit allowed for date palm seeds to this country (MAQIS, 2017). Importing any sources of plant to this country without getting the permit is illegal. Rules 5 Act of Quarantine 1976 and Rules of Plant Quarantine 1981 stated that importing any sources of plants are subject to necessity of getting import permit from the department of agriculture. Under section 19A Act of Quarantine 1976, subject to offense, person (s) can be charged not more than RM10,000 or jailed not more than two years or both (MAQIS, 2017). This requirement is important in order to ensure that the date palm seeds are free from pests and disease attacks, and obtain phytosanitary certificate from the export countries. Up to this issue, it is hard to get approval from department of agriculture as this plant is at high risk to disease and pests attacks.

\section{Lack of Expertise}

As date palm farming is relatively in small scale of plantation and equipped with only limited research conducted on date palm in Malaysia, it is believed that date palm farming is scarce of expertise, either in date palm research report or in practical field. Besides, lack of knowledge for dates palm farming, there are issues to be concerned although dates itself are acceptable as a healthy fruit in general public. Even there is a syndicate bring the dates palm trees to this country from Thailand, which is not permitted by the local authority due to insects' attack.

\section{Climate}

Climate change acts as a serious threat to climate sensitive sector of agriculture (Inbaraj et al., 2016). Located nearby the equator, Malaysia's climate is categorised as khatulistiwa, being hot and wet throughout the year. The average rainfall is $250 \mathrm{~cm}$ in a year and the average temperature is $27^{\circ} \mathrm{C}\left(80.6^{\circ} \mathrm{F}\right)$ (Herman et al., 2015). Moreover, Malaysia is featured with two monsoon wind seasons, the Northeast Monsoon from October to March and Southwest Monsoon from April to September. The Northeast Monsoon gets extra precipitation contrasted with the Southwest Monsoon, starting from China and the North Pacific. The southwest monsoon originates from the deserts of Australia. Meanwhile, during March 
and October form transitions between the two monsoons (Marshall, 2007).

Although Malaysia's climate has sufficient number of days with suitably high temperature to fully mature dates in date palms, continuous rainfall during the period of fruit maturation will affect the growth of dates. This climate condition makes dates farmers in the South Asian date-growing countries such as India and Pakistan, even Indonesia and Thailand which are near to Malaysia, choose to plant early bearing cultivars which are ripen before the annual monsoon rains or cooler weather. Alternatively, the fruits are harvested at khalal or rutab stages and artificially ripened; the latter involves extra labour costs. Thus, this also may become challenges that will affect date palm plantation in Malaysia.

\section{Soil Requirements}

Geographically disadvantaged as most of Peninsular, Malaysia is covered in tropical rainforest with a mountainous interior. Soil constraints affect the present and future prospects of date palm farms. $P$. dactylifera $\mathrm{L}$. are often mature in a very wide selection of soil varieties. Deep sandy soils with a good moisture supply are best (Abul-Soad, 2010). Good drainage and aeration are the most soil necessities for ideal production. Dates tree can grow in heavier soils; however, care should be taken not to waterlog these soils. It will grow in soils with high alkali and salt content, however the growth and productivity are going to be affected (Lemlem et al., 2018). In addition, sandy soils which have great drainage require more fertilization, as the fertilizers are more easily leached out by irrigation. Several components of the world where $P$. dactylifera $\mathrm{L}$. is grown still follow the traditional mixed planting of dates of varied ages at irregular spacing. Moreover, inadequate fertilizer application and lack of proper tree and bunch management, like pruning and fruit cutting, cause the assembly of low fruit quality and thus lower the market values. Therefore, it is such a challenge for date farmers in Malaysia to adapt to the soil necessities for the implementation of mass productivity scale (MPS).

\section{OPPORTUNITIES}

\section{Fulfilling Local Consumption Trends}

Along with the rising number of local population, the yield progress of the plant must increase in a very spare and proper manner to fulfil the increasing demand (Herman et al., 2015). Based on import-export data (see Table 1) of dates in Malaysia, it is undeniable fact that Malaysian are highly dependent on imported dates. Besides, supply chain for date products in Malaysia either as primary or secondary products is already established and date producers are highly needed in order to strengthen such supply chain. Therefore, efforts must be made to establish the date palm plantation in a mass productivity scale (MPS) to meet, especially, domestic demand. In this case, having large scale of date palm plantation is seen to become importance not only to reduce such dependency on imported dates, but also to meet local date-based products producers.

\section{Cultivation Nature}

Malaysia is known as a country with a high soil fertility level in the world. Statistics show that Malaysia is among the countries with large scale of commodity plantation such as rubber and palm oil. These commodity plantations are normally established with mass production, which are primarily concerned on meeting export demand worldwide. Besides, rubber and palm oil produced in Malaysia are in high quality. Thanks to elite cultivars practiced by Malaysian farmers, such production results in high quality of rubber and palm oil. Therefore, it is believed that having date palm plantation in a large scale in Malaysia would benefit especially on the quality of the date itself. This is because under elite cultivars, seedling dates often exhibit bigger tolerance to organic phenomenon and abiotic stresses; so, they will harbour genetic resources important to plant breeders and for that reason benefit scientific assessment (Johnson et al., 2013). Thus, to fulfil the increasing demand, the country needs to be ready to sustain date palm production and to identify process of 
gaining the crop yield per unit square, while not having to expand storage areas.

\section{Pest and Disease Management}

As previously mentioned that date palm is primarily threatened by the insect pest, date palm producers should be guided to form a good biosecurity standard through the adoption of the Good Agricultural Practices (GAP) to ensure the sustainability of date palm farming operations. This is owing to the fact that adopting GAP will increase competency in using better farming techniques, including land and water management, zero burning replanting techniques, integrated pest management, and biodiversity and quality assurance that will improve and assure date palms (Ben-Amor et al., 2019). Besides, date palm farmers also should be trained to identify any abnormality that may surface at their dates palm and to promptly report it to the relevant authorities. Meanwhile, at the state part, potency in diagnozing inflammation at the early stage by competent authority might additionally facilitate in lowering economic deficit.

The issue of global food security in the $21^{\text {st }}$ century is a major constraint (Herman et al., 2015). Thus, pest and disease management of $P$. dactylifera $\mathrm{L}$. are in necessary considerable research and development issues. The common pests' disease of dates in South Asia especially Malaysia are caused by Red Palm Weevil (R. ferrugineus Olivier, Coleoptera: Curculionidae) and Dubas bug (O. Iybicus Bergevin, Homoptera: Tropiduchidae) (Al-Yahyai and Manichavasagan, 2012). Chemical control of these pests has had limited success. Biochemical management of date pesterers has been shown to reduce pest populations (El-Sufty et al. 2007). However field application faces several constraints, as well as the ancient and poor tree and plantation management aforementioned.

\section{National Date Palm Centre}

While date palm health and disease are explored, artificial date palm planting in a large scale of farm is essentially needed to be done nationwide to create appropriate date palm plantation. National Date Palm Centre (NDPC) should be established and farmers need to be supported for maintaining private farming. The advantages of such a centre according to Shri and Dennis (2015) are: 1) to avoid costly duplication of exertion in tending to significant irritation and illness issues; 2) to enhance open doors for community oriented research both at the respective and global levels; 3) to develop and scatter data on best practices in date development, collection, postharvest care, and promotion by building up an intelligent site. $\mathrm{A}$ great model for date palm exists in Coconut Timeline (http://cocos.arecaceae.com); 4) to develop universal industry descriptors and guidelines for natural product quality and bundling and showcasing; 5) to maintain a database of world date palm cultivars and their preservation status; 6) to maintain data on date palm hereditary assorted variety, hereditary disintegration, protection, and usage of germplasm; 7) to develop programs on medical advantages of dates and different business nourishment items; 8) to develop date palm practical genomics for contemplating helpful qualities prompting hereditary improvement of date palm developing under environmental change, upgraded organic product quality, and modern items. It is apparent from the ongoing that one of the strongest justifications for MPS is the existing NDPC.

\section{Economics Value}

The considerable medicinal potential has led to the development of various commercial formulations such as pharmaceutical, foods, juices, healthcare products and original shape for the purpose human health. The parts of date palm such as fruit, pollen, seeds, trunk and leaves provide an antidot to a lot of illnesses and nutritional values to human (Abdullahi et al., 2012). The whole parts of $P$. dactylifera $\mathrm{L}$. are valuable, and the by-products arising from dates processing can be used for multiple ways. By-products from date palm are used in building structures, animal feed, and several other items, like baskets and ropes (Al-Yahyai and Manichavasagan, 2012). P. dactylifera L. are also used as food preparations like baking products, confectionary, snacks, sweets, healthy foods and institutional feeding. There wholesome savoury taste of all-natural sugar invites the most culinary creativity. As an ingredient to any recipe, dates provide the perfect natural alternative to added sugar (Sultana et al., 2015). Besides that, date palm is used as snacks, and low-quality ones are used as animal feeds (Dada et al., 2012). Dried dates are fed to camels, horses, goat's and dogs in Sahara Desert. According to Morton (1987), dry or soft dates are eaten out-of-hand, or may be seeded and stuffed, or slashed and used in a great multiple purposes: on bread, candy bars, ice cream, cereals, pudding, cookies and cakes. Thus, it would be the advantage 
for Malaysia's economics since the potentials of dates palm products are vast.

\section{Endowment of Dates Palm}

Last but not least, significant growing in date palm also can contribute to the growth in endowment especially on endowment of tree. In this case, the donor will contribute his or her wealth by purchasing trees for public use. Therefore, endowment tree benefits not only for human (such as fruit, tree and oxygen), but also for the ecosystem itself when its existence will balance the food chain among flora and fauna, and protect and cure the environment in nature. Besides, this deed also will be counted as part of worship and will be rewarded by Allah.

At present, there is an initiative on endowment tree by using date palms in Malaysia. This was initiated by Mr. Syful, an agriculture entrepreneur based in Ipoh, Perak who already provides endowment tree scheme since 2011. Currently, there are two types of date palms offered for endowment tree which are: 1) honey date palm; and 2) ajwa date palm. In this case, waqif will make endowment donation to Mr. Syful by purchasing date palm and at the same time will nominate the beneficiaries of those endowment trees. Next, Mr. Syful will fulfill donor intention by cultivating those endowment date palm at beneficiaries' places. Based on current practices, there are three types of endowment tree beneficiaries, which are: a) Islamic Mosques and Centre; b) Charitable and welfare organization (e.g. orphanage homes; old folks' homes and disabled centres); and c) Educational institutions (e.g. kindergardens, schools, religious schools, higher education institutions and universities).

By having endowment tree using dates palm, this indirectly will promote the growth of date palm cultivation in Malaysia. Besides, this good deed is believed to achieve multiple 'baraqah' or rewards from Allah due to its diversity and significant impacts towards peoples, environment, and charitable aspects.

\section{CONCLUSIONS}

The vital survey of the literature has acknowledged and verified the date farm problems on the base of challenges and opportunities. This study presented how date farm is being managed in Malaysia. As shown in this study, the challenge for all parties is clear that how each party could commit to improve date palm productivity in Malaysia. Although the farm managers are seen as the leaders in such endeavours, the participation and cooperation of the whole socity concerned within the date sector are essential. To be simpler, date farmers are challenged to be further innovative in their implementation of the date policies.

The farms problems driven from the essential survey of the literature are varied, however these are thought-about within the scheme approach to $P$. dactylifera L. NDPC are formed specifically to appear into and work to handle these problems. Each party involved in farm and the government agencies offer possible solutions to related issues. The date farmers offer associate environment and good-natured approach for the resolution of the problems; NDPC, on the opposite, present a coalition that may spearhead efforts to reverse the date palm state of affairs and produce regarding property. Attention, persistence, extra capital, association, collaboration and networking are their tools.

NDPC acknowledged that they will regularly face difficulties in their life as a structure body. On the opposite, they also aware of the chance to overcome the issues, provided that those chances are directly identified and taken into action. It will be up to all the ally collaborated to take up the challenges and expand the chance that come their way. As noted by Christie et al. (2007), enclosing the way as a guideline that benefits the people by promoting food security, property wealth process, and natural health could be the additional reasonable strategies of farms. However, it will drift for a body to make it about within the case of Asian nation as NDPC gift is such a relevant and well-placed body.

$P$. dactylifera L., amongst the greatest beneficial fruits at numerous parts of the universe, are usually characterized by arid, high-temperature climate. Date commodity trade has been steadily rising in recent years, reflecting greater demand from all five continents of the world. Date palm constitutes a major source of food and its by-products can be utilized in a range of items from construction to clothing. This makes date palm an ideal crop for low-income countries, where poverty and hunger prevail. This review can serve as a good reference material for researchers who aim at improving date production in MPS by optimising the opportunities recommended in this study. 


\section{ACKNOWLEDGEMENTS}

This research was funded by the Ministry of Higher Education (MOHE) under the Niche Research Grant Scheme (NRGS) USIM/NRGS_P6/FEM/8406/52113. Faculty of Economics and Muamalat, Universiti Sains Islam Malaysia.

\section{REFERENCES}

Abdullahi, M. H. and M. Garko. 2012. Medicinal value of date palm (Phoenix dactylifera L.). Proceeding of the Conference in Agricultural Society of Nigeria. https://www.researchgate.net/publication/233934299_Medicinal_v alue_of_Date_palm_Phoenix_dactylifera_L.

Abul-Soad, A. A. 2010. Impact of rain fall and floods on the fruit and trees of date palm in Pakistan. Bless Tree., 2: 56-59.

Al-Farsi, M., C. Alasalvar, M. Al-Abid, K. Al-Shoaily, M. Al-Amry, and F. Al-Rawahy. 2008. Compositional and functional characteristics of dates, syrups, and their by-products. Food Chemistry., 104: 943-947.

Al Kharusi, L., R. Sunkar, R. Al-Yahyai, and M. W. Yaish. 2019. Comparative water relations of two contrasting date palm genotypes under salinity. International Journal of Agronomy, 1-16.

Al-Shahib, W. and J. R. Marshall. 2003. The fruit of the date palm: its possible use as the best food for the future?. International Journal of Food Sciences and Nutrition., 54: 247-59.

Al-Yahyai, R. and A. Manichavasagan. 2012. An overview of date palm production, p. 3-12. In: Manichavasagan, A., M. Essa and E. Sukumar (ed.). Dates production, processing, food and medicinal values. USA: CRC Press, Boca Raton, FL.

Apriyanti, R. N.; E. Pujiastuti, and D. S. Rahimah. 2015. Kurma dari gurun ke tropis. [Dates palm from desert to tropical] $\left(12^{\text {th }}\right.$ ed.). Indonesia: Trubus Swadaya, Jakarta.

Ben-Amor, R., M. D. de Miguel Gomes, D. M. Habib, H, Nouha, and E. Aguayo. 2019. Freezing treatments for ectomyelois ceratoniae mortality and maintenance of deglet noor palm date quality. Journal of Food Quality, 1-9.

Christie, P., D. L. Fluharty, A. T. White, L. E. Osorio and W. Jatulan. 2007. Assessing the feasibility of ecosystem-based fisheries management in tropical contexts. Marine Policy, 31: 239-250.

Dada. M., C. N. Nwawe, R. A. Okere, and I. O.
Uwubanmwen. 2012. Potentials of date palm tree to the Nigerian economy. World Journal of Agricultural Sciences., 8: 309-315.

Djamil, S. A. 2016. Kurma Indonesia. [Indonesia dates palm]. http://www.kampungkurma.com/wpcontent/uploads/2016/12/Ebook-TentangKurma.pdf.

Dowson, V. H. W. 1982. Date production and protection with special reference to north Africa and the near east. Federal Agriculture Organization Technical Bulletin., 35: 294.

El-Sufty, R. S., A. Al-Awash, A. M. Amiri, A. S. Shahbad, A. H. Al Bathra, and S. A. Musa. 2007. Biological control of red palm weevil, Rhynchophorus ferrugineus (Col.: curculionidae) by the entomopathogenic fungus Beauveria bassiana in United Arab Emirates. Acta Horticulture., 736: 399-404.

ETP. 2010. Agriculture: Entry point project 7: Premium fruits and vegetables. Economic transformation program. http://etp.pemandu.gov.my/Agriculture-@-Agriculture_-_EPP_7-;_Premium_ Fruits_and_Vegetables.aspx.

FAMA. 2014. Statistik utama pemasaran lembaga pemasaran pertanian persekutuan: Edaran umum [Federal Agricultural Marketing Authority (FAMA) main marketing statistics: public circulation].http://www.fama.gov.my/documents/10157/f3d27dd0-f3a3-4d94-ac01-bf5 dd08022ec.

FAO. 2015. Statistical pocketbook (World food and agriculture). Food Agriculture Organization (FAO). $h t t p: / / w w w . f a o . o r g / 3 / a-i 4691$ e.pdf.

Herman, T., A. Warsi, E. Murchie, and A. Ali. 2015. Rice production and climate change: A case study of Malaysian rice. Pertanika Journal Tropical Agricultural Science., 38: 321 - 328.

Haris, A., A. F. Kamarubahrin, N. A. Muhamed, N. Ahmad, S. N. M. Daud, Z. K. Zulkefli, S. A. Shukor. and A. H. M. A. Qadir. 2019. Dates consumption in Malaysia. The Malaysian Journal of Islamic Sciences., 26: 47-52.

Haris, A., Z. K. Zulkefli, N. Ahmad, S. N. M. Daud, N. A. Muhamed, S. A. Shukor, and A. F. Kamarubahrin. 2017. Consumers' intention to purchase dates: application of Theory of Reasoned Action (TRA). Malaysian Journal of Consumer Family Economics, 20: 1-15.

Haris, A. and A. F. Kamarubahrin. 2016. A study of Malaysian education and purchasing patterns on propheticfoods, p. 207-216. In: Zulkifli, M. Y., K. Ahmad. and M. Abd Razzak (ed.), Research on foods: Nabawi and scientific perspective. 
Malaysia: University of Malaya Publisher, Kuala Lumpur.

Inbaraj, S., V. Sejian, B. Madiajagan, and R. Bhatta. 2016. Impact of heat stress on immune responses of livestock: A review. Pertanika Journal Tropical Agricultural Science, 39: 459 - 482.

Ismail, B., I. Haffar, R. Baalbaki, Y. Mechref, and J. Henry. 2006. Physio-chemical characteristics and total quality of five date varieties grown in United Arab Emirates. International Food Science and Technology, 41: 919-926.

Johnson, D. V., J. M. Al-Khayri, and S. M. Jain. 2013. Seedling date palms (Phoenix dactylifera L.) as genetic resources. Emirates Journal of Food and Agriculture, 25: 809-830.

Kamarubahrin, A. F. 2019. Muslim consumer intention toward goat milk purchasing behaviour in Malaysia: A preliminary findings. International Journal of Management, Accounting and Economics, 6: 62-79.

Kamarubahrin; A. F. A. Haris; S. A. Shukor, and J. A. N. Shaari. 2019. Exploring the motive of Muslim consumers' intention toward goat's milk purchasing in Malaysia: A focus group interview. Muqtasid: Jurnal Ekonomi dan Perbankan Syariah, 10: 30-39.

Kamarubahrin, A. F., A. Haris, S. A. Shukor, S. N. M. Daud, N. Ahmad, Z. K. Zulkefli, N. A. Muhamed, and A. H. M. A. Qadir. 2019. An overview Malaysia as a hub of planting prophetic fruits. Malaysian Journal of Sustainable Agriculture, 3: 1-7.

Kamarubahrin, A. F., M. I. H. Kamaruddin, A. Haris, S. N. M. Daud, Z. K. Zulkefli, N. Ahmad, S. A. Shukor, and N. A. Muhamed. 2018a. Dates palm farming in Malaysia: Current challenges and future baraqah, p. 260-268. In: Supaat, D. I., A. A. Ghafar. and I. Wook. Contemporary issues: Islamic and science. Malaysia: Universiti Sains Islam Malaysia Publisher, Negeri Sembilan.

Kamarubahrin, A. F., A. Haris, S. N. M. Daud, Z. K. Zulkefli, N. Ahmad, N. A. Muhamed, and S. A. Shukor. 2018b. The potential of pumpkin (Cucurbita moschata duschene) as commercial crop in Malaysia. Pertanika Journal of Scholarly Research Reviews, 4: 1-10.

Lemlem, A., M. Alemayehu, and M. Endris. 2018. Date palm production practices and constraints in the value chain in Afar Regional State, Ethiopia. International Journal of Agronomy, 1-10.

Marshall, C. 2007. World and its peoples: Eastern and southern Asia (Malaysia, Singapore, Brunei and the Philippines). Bangladesh: Marshall Cavendish Corporation.

MAQIS. 2017. Prosedur import [Import procedure]. Malaysian Quarantine and Inspection Services (MAQIS). http:// www.maqis.gov.my /tumbuhan-prosedur-import.

Mohamed, S. S., A. P. L. Ling, C. L. Lim, S. M. Chye and R. Y. Koh. 2018. A mini review on phytochemical constituents and pharmacological activities of adenium obesum. Pertanika Journal Tropical Agricultural Science, 41: 591 - 604

Morton, J. 1987. Date. In: Fruits of warm climates, p. 5-11. Miami, FL : Creative Resource Systems Inc.

Musselman, L. J. 2007. Figs, dates, laurel and myrrh: Plants of the bible and the Quran. Portland, OR: Timber Press, Inc.

Popenoe, P. B. 1973. The date palms, p. 247. In: Field. H. (ed.). Coconut, Miami, FL.

Rani, M. D. M.; N. S. Umar; S. Ramli; Z. A. Rahman; M. Y. Abdullah and S. M. Salleh. 2016. Knowledge of prophetic food consumption in Malaysia: Halal, health benefits and practices. p. 499-508. In: Ab. Manan S., F. A. Rahman. and M. Sahri (ed.) Contemporary issues and development in the global halal industry. Singapore: Springer.

Serhane, H., L. Amro, H. Sajiai, and A. A. Yazidi. 2017. Prevalence of skin sensitization to pollen of date palm in Marrakesh, Morocco. Journal of Allergy, 1-13.

Shri., M. J. and V. J. Dennis. 2015. Date palm genetic recourse and utilization. In: Al-Khayri, J. M. (ed.). Berlin: Springer.

Sultana, P., E. Dilruba, A. Sheikh, M. Biswas, S. C. Dev Sharma, M. G. S. Jahan, M. A. Islam, N. Roy, and M. S. Shovon. 2015. Nutritional analysis of date fruits (Phoenix dactylifera L.) in perspective of Bangladesh. American Journal of Life Sciences, 3: 274-278.

Umar, N. S., M. D. M. Rani, T. S. A. Rahman, and N. M. Salleh. 2016. A review of prophetic nutraceutical foods: Issues and challenges. Advanced Science Letters., 22: 2147-2151.

Vayalil, P. K. 2012. Date fruits (Phoenix dactylifera L.): An emerging medicinal food. Critical Reviews in Food Science Nutrition, 52: 249-271.

Young, I., A. Rajić, S. Hendrick, S. Parker, J. Sanchez, J. T. McClure, and S. A. McEwen. 2010. Attitudes towards the Canadian quality milk program and use of good production practices among Canadian dairy producers. Preventive Veterinary Medicine, 94: 43-53. 
Zaid, A. and P. F. de Wet. 2002. Botanical and systematic description of the date palm, 156(1). In: A. Zaid and E. J. Arias-Jiménez (ed.). Date palm cultivation. Italy: Federal agriculture organization plant production and protection, Rome
Zainal, H. 2016. Ladang kurma di Pontian. [Dates farm in Pontian]. https://www.utusan.com.my/berita/wilayah/johor/ladangkurma-di-pontian-1.379412. 